\title{
THE CORRELATION OF PROSPECTIVE TEACHERS' TENDENCY OF \\ CRITICAL THINKING AND THEIR CRITICAL THINKING SKILLS TOWARDS THEIR LEARNING OUTCOMES
}

\section{Yayuk Andayani ${ }^{\bowtie}$}

Natural Science Education Program, Postgraduate Program of Universitas Mataram, Indonesia

\section{Article Info}

Received April 2018 Accepted June 2018 Published July 2018

\section{Keywords:}

Critical Thinking Skills, Critical Thinking Tendency, Learning Outcome, Projectbased Learning

\begin{abstract}
This research employs Ex Facto approach to analyse the relation between prospective teachers' critical thinking tendency (CTT) and their critical thinking skills (CTS) towards their learning outcome. The subject of this research the fifth semester students of Chemistry Education, Faculty of Teaching, Universitas Mataram academic year of 2017/2018. The research focuses on the teaching of Chemical Physics III subject to 40 people who are chosen under purposive sampling method. The variable of attribute is the use of project-based learning and CTT while the dependent variable is the CTS and students' learning outcome. The data of CTT were obtained through questionnaires focusing on the matter while the students' CTS and learning outcome were measured using essay tests. The analysis of the data utilizes Pearson correlation test. The result of the test showed significant relevance between CTT and CTS ( $r_{\text {count }} ; 0.341>r_{\text {table }} ; 0.312$ ). Meanwhile, the total of CTT and learning outcome do not show significant coexistence $\left(\mathrm{r}_{\text {count }} ; 0.096<\mathrm{r}_{\text {table }} ; 0.312\right)$, even though the indicator of open-mindedness displayed a significant coherence to learning outcome $\left(\mathrm{r}_{\text {count }} ; 0.449>\mathrm{r}_{\text {table }} ; 0.312\right)$. Based on the result, to sum up, there is a significant relation between critical thinking tendency and critical thinking skills.
\end{abstract}




\section{INTRODUCTION}

Critical thinking is a highly prioritized competence in education. The skills become a challenge for modern educators to instil it in their students' mind. Different method of learning model should be developed to train students critical thinking skills (Lang, 2001). Critical thinking is a required skill to succeed in life, and the skills can be sharpened through learning process (Biber, et al 2013).

According to Sendag, et al (2015), there are three main components of critical thinking, which are: (a) critical thinking tendency; (b) learning experience; and (c) critical thinking skills. First, the critical thinking tendency is a direction of being critical (Norris, 1989); second, mastering adequate information is an essential thing for individual to think critically; learning experience is important for problem solving, decision making, and evaluating mindset (Willingham, 2008). Using their experience, people will solve problem by inventing new ideas of which they can be wiser in making decision (Riyanti, et al, 2016); and third, critical thinking skills is related to the high order thinking skills. Facione (2011) argues that critical thinking has two components, which are cognitive critical thinking skills and critical thinking tendency. Cognitive critical thinking skills are the intellectual aspects of critical thinking; meanwhile, critical thinking tendency is people's perspective on certain problem and the influence of both components of critical thinking to each other.

The success of education is strongly affected by different factors: input and learning process. Input is the level of critical thinking tendency owned by students. Meanwhile, the learning process is the learning model applied by the teachers in the classroom. In relation to this, project-based learning is a learning model which can improve students' critical thinking skills, since the implementation of the model includes various strategies of thinking for the sake of students' learning success in the $21^{\text {st }}$ century (Bell, 2010., Ravitz et al, 2012). Some researches have proven that project-based learning influences students' critical thinking skills (Hidayat et al, 2014., Sastrika et al, 2013., and Mulyani et al, 2015).

The parameter of success to a learning process does not only lies on the ability to train certain skills, but it is also related to students' learning achievement. The learning outcome of the students grows based on some factors. Based on Suhaily and
Soelasih (2015), the dominant factor which affects students' learning outcome is the students themselves. In details, success students are more active in the class than the unsuccessful ones.

This research aims to analyse the correlation between critical thinking tendency and critical thinking skills to students' learning outcome for Chemical Physics III subject in the Faculty of Teaching of Universitas Mataram.

\section{METHODS}

This research uses Ex Post Facto approach with students' Critical Thinking Skills (CTS) and learning outcome, while the attributive variable is the Critical Thinking Tendency and project-based learning as the implemented learning model. The subject of this research is 40 students of Chemical Physics III class of Faculty of Teaching in Universitas Mataram.

The data of students' critical thinking skills and learning outcome were obtained through essay tests. Meanwhile, the data of critical thinking tendency were obtained through questionnaires which contains 63 questions representing 7 indicators of critical thinking by Facione (1990). The questionnaire features options of answer based on likert scale from 1 to 6 , starting from very agree to very disagree. Each indicator have 9 questions with the score range of 9 to 54 ; thereby, the overall score ranges from 63 to 378 (Tiwari et al., 2003). The data were then analysed using the correlation test using the 2.0 version of SPSS for windows.

\section{RESULTS AND DISCUSSION}

Based on the table 1 below, the indicators which have strong correlation to critical thinking skills are open-mindedness and inquisitiveness (curiosity). However, the overall conclusion shows that there is a significant connection between critical thinking tendency and skills. Facione et al (1997), Ricketts and Rudd (2004), and Profetto, J (2003) also find that there is a positive and significant relation between both elements. The finding shows that students with strong tendency of critical thinking will have strong critical thinking skills. The statement shows that the influencing factor to critical thinking improvement of the students has already existed in students' mind. The internal factor supports the behavioural model of theoretical framework by Ricketts, and Rudd (2004). They explain that critical thinking is a 
behaviour formed by the combination of perspective and other attributed elements, like gender, age, and grade point average.

Table 1.The correlation between CTT and CTS $(n=40)$

\begin{tabular}{|c|c|c|c|}
\hline \multirow{9}{*}{$\begin{array}{l}\text { Critical } \\
\text { Thinki } \\
\text { ng } \\
\text { Skills }\end{array}$} & $\begin{array}{l}\text { Indicators of } \\
\text { CTT }\end{array}$ & $\mathrm{p}$ & $\mathrm{r}$ \\
\hline & Truth-seeking & 0.599 & \\
\hline & $\begin{array}{l}\text { Open- } \\
\text { mindedness }\end{array}$ & $0.029 *$ & \\
\hline & Analytics & 0.352 & \\
\hline & Systematics & 0.223 & \\
\hline & Self-confident & 0.998 & \\
\hline & Inquisitiveness & $0.004^{*}$ & \\
\hline & Maturity & 0.789 & \\
\hline & $\begin{array}{l}\text { Overall CTT } \\
\text { score }\end{array}$ & $0.031^{*}$ & \\
\hline
\end{tabular}

CTS is a sign of an intellectual behavior. Facione (2009) groups the disposition of critical thinking into seven indicators, which are: (1) truthseeking (the habit of craving best explanation to certain situation with strong reasons and empirical evidences), (2) open-mindedness (a tendency of acknowledging other people's opinion), (3) analytics (a strong attentive behaviour of anticipating sequences of event), (4) systematics (a habit of working hard and solving problems with disciplinary conduct),(5) Confidence (rational and reflective mindset for solving problems), (6) Curiosity (a tendency of being curious to everything), and (7) Maturity (cognitive maturity on handling complicated matters, making precise judgment, and avoiding procrastination.

The CTS of this research contains the 5 of 6 elements mentioned by Facione (1990), which are (1) interpretation (ability to comprehend and explain meaning or significance of wide variation from different experience), (2) analysis (ability of identifying the relation of various elements), (3) evaluation (ability to test the credibility of a statement), (4) inference (ability of identifying and choosing element to create logical conclusion), and (5) explanation (ability to state thoughts and to provide empirical reason for that).

However, beside the internal factor of the students, their critical thinking also comes from their learning process. The process facilitates the internal factors to develop optimally. Project-based model is a learning model which includes mandating students to do sequences of activities, including observation, making hypothesis or prediction, planning the implementation of activity, interpreting and analyzing, making conclusion, and communicating the conclusion. Sastrika, et al (2013) mentions that project-based learning is a learning model which focuses on process and problems with relative learning duration. The learning unit will combine the concepts of different components, such as knowledge, science discipline, or empirical facts. The students become the centre of the process who attempt to involve, collaborate, and participate in the learning process.

Project-based model is an innovative learning model which emphasizes on contextual learning process. The learning process includes complex materials from the concepts of certain disciplines and demands the students to investigate in solving problems autonomously to construct their own understanding; later, it is expected that the students will produce a real product from that (Karinal et al., 2014).

The indicators of CTT which show positive and significant correlation to CTS are the Openmindedness and Inquisitiveness. Both of them show positive connection to CTS due to the influence of the syntaxes of learning process (Pananasan \& Nuangchalerm, 2010). The growth of these characters can lead the students to think critically to achieve the expected outcome.

In line with the research of Sastrika, et al., (2013), project-based learning can sharpen the students' CTS by exposing them ways to find a solution and achieve the objective of the learning process. As in Verma, et al (2011) and Wusqo et al (2015), project-based learning can improve the involvement of the students as well as motivate them to improve their academic achievement (Ocak \& Oluyol, 2010).

Table 2. The Correlation between CTS to learning outcome $(n=40)$

\begin{tabular}{llll}
\hline & Indicators of CTT & $\mathrm{p}$ & $\mathrm{r}$ \\
\cline { 2 - 4 } & Truth-seeking & 0.289 & -0.172 \\
\cline { 2 - 4 } Learning & Open-mindedness & $0.004^{*}$ & 0.449 \\
\cline { 2 - 4 } Outcome & Analytics & 0.546 & -0.098 \\
\cline { 2 - 4 } & Systematics & 0.880 & -0.025 \\
\cline { 2 - 4 } & Self-confident & 0.657 & -0.072 \\
\cline { 2 - 4 } & Inquisitiveness & 0.074 & 0.285 \\
\cline { 2 - 4 } & Maturity & 0.815 & -0.038 \\
\cline { 2 - 4 } & Overall CTT score & 0.554 & 0.096 \\
\hline
\end{tabular}

Generally, CTT does not have significant 
impact to learning outcome (Table 2), yet, the indicator of open-mindedness projects weak positive significance. Similar to the explanation, Karagöl \& Bekmezci (2015) theorizes that there is a positive and weak relation between critical thinking skills and academic achievement. The weak relation is suspected due to the implementation of unfamiliar learning strategy, as it is not integrated into the curriculum's system. The tendency of critical thinking builds after several amount of time (Fong et al., 2017).

Lately, the finding shows that students' character can influence their learning outcome. Students with open mind are open to argumentation and new ideas in the learning process. Thus, these ideas become a supplementary input for the learning process is not only about presenting concepts and theories to remember, but it is about the way to make people understand the package of knowledge, behaviour, values, and skills. Learning process is done by giving students flexibility to find solution of their problems by themselves or cooperating with others (Riyanti, et al.,2016). This freedom results a meaningful nuance to learning process. Additionally, Trianto, (2011) says that project-based model has higher potential to attract students' interest of learning with advantageous result.

According to Rati et al., (2017) and Utami, et al., (2013), project-based learning positively influences the students' learning outcome. With more joyful learning, the students feel challenged to improve their achievements. Besides, the students are free to express their thoughts in decision making. They feel more appreciated in the classroom that it impacts their spirit of learning. The students are also trained to analyse and synthesize the information from the lecturer. In conclusion, open minded students have more potentials of achieving more optimum learning outcome.

\section{CONCLUSION}

Based on the results and discussion, there is a positive and significant correlation between students' critical thinking tendency and critical thinking skills. However, the positive and significant correlation is absence in students' learning outcome.

\section{REFERENCES}

Bell, S. (2010). Project-Based Learning for the 21st Century: Skills for the Future. The Clearing House, 83: 39-43. Copyright C_ Taylor \& Francis Group, LLC.

Biber, A., Abdulkadir, T., \& Lutfi., I. (2013). An investigation of critical thinking dispositions of mathematics teacher candidates. Educational Research.4 (2) :109-117

Facione, A. (2011). Critical Thinking: What It Is and Why It Counts. Measured Reasons and The California Academic Press, Millbrae, CA.

Facione, P. A. (2009). Critical thinking: What it is and why it counts.

http://www.insightassessment.com/ pdf_files/what\&why2009.pdf

Facione N.C. \& Facione P.A. (1997) Critical Thinking Assessment in Nursing Education Programs: An Aggregate Data Analysis. The California Academic Press, Millbrae, CA, USA

Facione, P.A. (1990). Critical Thinking : A Statement of Expert Consensus for Purposes of Educational Assesment and Instruction. Executive Summary "The Delphi Report". California Academi Press : Millbrae. Diakses 11 juli 2016.

Fong, C .,Y Kim.,C.W. Davis and Y.W Kim. (2017) A Meta Analysis on Critical Thinking and Community College Student Achievement Thinking Skills and Creativity. 26:71-83

Hidayat, S., Susilawati, \& Harry, S. (2014). Pengaruh Model Pembelajaran Berbasis Proyek Terhadap Penguasaan Konsep Ditinjau Dari Keterampilan Berpikir Kritis Pada Mata Kuliah Optik. Jurnal Ilmiah Pendidikan Fisika "Lensa". 2: (2)

Karagöl \& Bekmezci. (2015). Investigating Academic Achievements and Critical Thinking Dispositions of Teacher Candidates. Journal of Education and Training Studies. 3 (4): 86-92

Karinal,N.K.D., Sadia, I. W. \& Suastra, I.W. (2014). Pengaruh Model Pembelajaran Berbasis Proyek Terhadap Kemampuan Pemecahan Masalah \& Kecerdasan Emosional Siswa Smp. e-Journal Program Pascasarjana Universitas Pendidikan Ganesha Program Studi IPA. 4.

Lang, K.S. (2001). Critical Thinking Dispositions of Pre-service Teachers in Singapore: A Preliminary Investigation. Paper presented at the Annual Conference of the Australian Association for Research in Education (AARE). 
Mulyani N.K.s, Karyasa, I.W \& Suardana, I.N. (2015). Komparasi Peningkatan Keterampilan Berpikir Kritis Dan Kinerja Ilmiah Siswa Yang Dibelajarkan Dengan Model Project Based Learning dan Model Pembelajaran Inkuiri Terbimbing. e- Journal Program Pascasarjana Universitas Pendidikan Ganesha Program Studi Pendidikan IPA.

Norris, S. P. (1989). Can we test validly for critical thinking? Educational Researcher. 18 (9): 2126.

Ocak, M., \& Uluyol, Ç. (2010). Investigation of college students' intrinsic motivation in project based learning. International Journal of Human Sciences, 7: 1152-1169.

Pananasan \& Nuangchalerm. (2010). Learning outcomes of project based and inquiry based learning activities. Journal of social sciences. 6 (2) :252-255

Profetto, J. (2003). The relationship of critical thinking skills and critical thinking dispositions of baccalaureate nursing students. Journal of Advanced Nursing, 43 (6): 569-577

Rati, N.W., Kusmaryatna, N \& Rediani, N. (2017). Model Pembelajaran Berbasis Proyek, Kreativitas dan Hasil Belajar Mahasiswa. Jurnal Pendidikan Indonesia. 6 (1)

Ravitz, Z., Nate, H., Mary, E., \& John, M. (2012). Using project based learning to teach 21st century skills: Findings from astatewide initiative. Paper presented at Annual Meetings of the American Educational Research Association.

Ricketts, J.C. \& Rudd.R. (2004). The Relationship between Critical Thinking Dispositions and Critical Thinking Skills of Selected Youth Leaders in the National FFA Organization. Journal of Southern Agricultural Education Research.54 (1): 21-33

Riyanti, A., Widiyatmoko, A., \& Wusqo, I. U. (2016). Pengaruh Model Pembelajaran Kooperatif Tipe Team Assisted Individualization Berbantuan Peta Konsep Terhadap Hasil Belajar dan Keterampilan Berpikir Kritis Siswa SMP Tema Kalor. Unnes Science Education Journal, 5(2):1280-1287

Sastrika,I.A.K. Sadia,I.W. \& Muderawan,I.W. (2013). Pengaruh Model Pembelajaran Berbasis Proyek Terhadap Pemahaman Konsep Kimia dan Keterampilan Berpikir Kritis. e-Journal Program Pascasarjana Universitas Pendidikan Ganesha Program Studi IPA .3.
Sendag, S., Osman, E., Sezan, S., \& Nihal, D. (2015). Preservice Teachers' Critical Thinking Dispositions and Web 2.0 Competencies. Contemporary Educational Technology. 6(3): 172-187.

Suhaily;L \& Y. Soelasih. (2015). Factors Affecting Student Achievement In Faculty Of Economics "X" University. Journal The WINNERS. 16 (1): 25-35

Tiwari, A., Alan, A., \& Patrick, L. (2003). Critical Thinking Disposition of Hong Kong Chinese and Australian Nursing Students. Journal of Advanced Nursing. 44 (3): 298-307

Trianto. (2011). Model Pembelajaran Terpadu. Jakarta: Bumi Aksara.

Utami, N.R. Andayani, A. \& Muntari. (2013). Pengaruh Model Pembelajaran Berbasis Proyek Terhadap Prestasi Belajar Kimia Siswa Kelas XI IPA SMAN 1 Narmada Tahun Pelajaran 2013/2014. Jurnal Pijar MIPA. $8 \quad$ (2), tersedia pada http://jurnalfkip.unram.ac.id/index.php/J $\mathrm{PM} /$ article/view/81

Verma, A., Dickerson, D., \& McKinney, S. (2011). Engaging students in STEM careers with project-based learning-Marine Tech Project. Technology and Engineering Teacher. 71(1) : 2531.

Willingham, D.T. (2008). Critical thinking: Why is it so hard to teach? Arts Education Policy Review, 109 (4), 21-32.

Wusqo, I. U., Taufiq, M., \& Handayani, R. (2015). Development Assessment Of Alternative Practicum II Basic Chemical Through Chemistry Fair Project (CFP) Based Conservation Using Chemical Daily. Jurnal Pendidikan IPA Indonesia, 4(2):135-144. 